\title{
The effect of age on the frequency of adverse reactions caused by antimony in the treatment of American tegumentary leishmaniasis in Governador Valadares, State of Minas Gerais, Brazil
}

\author{
Doracy Silva Diniz ${ }^{[1]}$, Alexandre Sylvio Vieira $\operatorname{Costa}^{[1]}$ and Patrícia Maria Fonseca Escalda ${ }^{[2]}$
}

[1]. Direção do Centro de Ciências Agrárias, Universidade Vale do Rio Doce, Governador Valadares, MG. [2]. Curso de Saúde Coletiva, Faculdade de Ceilândia, Universidade de Brasilia, Brasília, DF.

\section{ABSTRACT}

Introduction: Governador Valadares is an endemic area of American tegumentary leishmaniasis (ATL). The detection rate was 15.36 per 100,000 habitants from 2001 to 2006 (Miranda, 2008). This study aimed to analyze the effects of age on the frequency of adverse reactions caused by antimony in the treatment of ATL in the City of Governador Valadares, State of Minas Gerais, Brazil, during 2009. Methods: Data were collected from the forms of the Information System for Notifiable Diseases, and from charts, questionnaires, and home visits to patients. Results: The study included 40 patients, 26 (65\%) of whom were males. Individuals over the age of 50 had a $66 \%$ higher rate of adverse effects than subjects who were 50 years old or less ( $\mathrm{Cl} 95 \%, 1.14-2.41)$. The average age of individuals who reported some type of adverse effect was 44.11 years $(S D=20.14)$, while the average age of the group that did not report any adverse effect was of 25.46 years (SD $=18.37$; $p<0.01$ ). Clinical healing was $67.5 \%$, and $10 \%$ of patients discontinued the treatment. Conclusions: In the treatment of ATL, the age of patients should be considered, because most adverse reactions occur in individuals over 50 years of age. For this reason, the drug should be used with restriction in these cases.

Keywords: American tegumentary leishmaniasis. Treatment. Governador Valadares.

\section{INTRODUCTION}

For the treatment of American tegumentary leishmaniasis (ATL), the first drug of choice is pentavalent antimony. The Ministry of Health recommends 10 to $20 \mathrm{mg} / \mathrm{kg} /$ weight dosage per day of pentavalent antimony for 20 days. There may be a second treatment cycle for 30 days when lesions are not healed after completing 90 days of the first cycle ${ }^{1}$.

Patients may present some adverse effects from medication, such as arthralgia, myalgia, inappetence, nausea, vomiting, gastric fullness sensation, epigastric pain, heartburn, abdominal pain, rash, fever, weakness, headache, dizziness, and insomnia. Fatal arrhythmias are rare, and there are few cases of sudden death ${ }^{2}$. Patients over 50 years old with a heart condition, kidney failure, liver disease, and Chagas disease should undergo previous cardiologic evaluation, since for such individuals the toxicity of the drug is increased. The use of pentavalent antimony is contraindicated for pregnant women, because these drugs may cause abortion; these drugs cross the transplacental barrier and may impregnate the nervous tissue of the fetus, leading to severe mental retardation syndromes. In these cases, the treatment involves local care, clinical observation, and the use of amphotericin $\mathrm{B}^{1,3}$.

The therapeutic response to treatment with pentavalent antimony has so far not been satisfactory. According to different authors, the success rate varies from $26 \%$ to $100 \%$ of patients treated after a first period of antimony administration ${ }^{4-8}$. In another study conducted in Cuiabá, State

Address to: Ms. Doracy Silva Diniz. Laboratório de Solos/UNIVALE. Rua Israel Pinheiro 2000, Campus II, Bloco A 4, Bairro Universitário, 35020-220 Governador Valadares, MG, Brasil.

Phone: 5533 3279-5990

e-mail: doracydiniz@hotmail.com.br

Received in 27/05/2011

Accepted in 04/10/2011 of Mato Grosso, Brazil, the failure rate was $47 \%$, that is, no healing or recrudescence of skin lesions was found during the three month followup after the first treatment regimen?.

The aim of this study was to analyze the effect of age on the frequency of adverse effects caused by antimony in the treatment of patients with ATL in Governador Valadares, State of Minas Gerais, Brazil.

\section{METHODS}

The study was conducted at Dr. Alexandre Castelo Branco (CREDEN-PES), a Referral Center for Endemic Diseases and Special Programs of the Municipal Health Department of Governador Valadares, State of Minas Gerais, Brazil, as the city is a regional referral center for health care ${ }^{10}$.

All individuals diagnosed with ATL and treated at CREDEN-PES from January to December 2009 were eligible for this study.

The following were used as information sources for this study: the Information System for Notifiable Diseases (SINAN) American tegumentary leishmaniasis notification form, and as additional sources, patient charts and questionnaires answered directly by the patients through face-to-face interviews.

The economic and sociodemographic variables studied were gender, age, place of residence, occupation, marital status, level of education, household income, and race/color.

The clinical and epidemiological variables were diagnosis and treatment as well as anthropometric measurements and clinical evolution.

For the diagnosis and treatment the following were studied: parasitological and immunological tests; histopathological and complementary tests; response to treatment; monitoring of the first, 
second, and third medical consultations during the treatment period; weight, clinical evolution, and time between onset of symptoms and diagnosis; and comorbidities, adverse reactions, and regular treatment. Individuals diagnosed with ATL underwent treatment with pentavalent antimony (glucantime) as a first drug of choice. The doses were from 10 to $20 \mathrm{mg} / \mathrm{Sb}^{+5} / \mathrm{kg} /$ day for 20 consecutive days for the cutaneous form, and $20 \mathrm{mg} / \mathrm{Sb}+5 / \mathrm{kg} /$ day for 30 consecutive days for the mucosal form, following the therapeutic scheme recommended by the Ministry of Health.

Clinical evolution was monitored through medical records for three months after the patient received the treatment regimen. Thus, for the conclusion of cases the following situations were considered: healing, nonhealing, and treatment abandonment. The criteria for clinical healing were epithelialization of ulcerative lesions, total regression of the infiltration, and erythema. Non-healing was considered when healing of the lesion was not complete within three months after the treatment regimen. Treatment was considered abandoned when healing of the lesion was not complete and the patient did not show up 30 days after the third appointment, which occurs when the third month of treatment regimen ends.

The study population was monitored up to three months after completion of the treatment regimen. According to the Ministry of Health, this is the time set for ending the case in SINAN because during such time it is possible to evaluate the clinical evolution after the use of ATL medication.

The questions used for data collection were coded, and later an instrument for electronic data collection based on the questionnaire categories was created to process and store data in Epilnfo/WHO. The difference between proportions was assessed using the chi-square or Fisher exact test when at least one of the cells of the table had a value below 5 , with a significance level of $5 \%(p<0.05)$. Differences between the averages were tested by Student's t test, with a significance level of $5 \%(p<0.05)$. The Odds ratios (OR) test and confidence interval $(\mathrm{Cl})$ of $95 \%$ which were estimated by logistic regression to identify the effect of independent variables upon the dependent variable.

\section{Ethical considerations}

The study was approved by the Ethics Committee on Human Research at the University Vale do Rio Doce, Governador Valadares, MG, filed under №. PQ 025/07-11.

\section{RESULTS}

In the period from January to December 2009, 42 individuals with ATL were reported at CREDEN-PES. Of this population, 40 individuals were studied; there was a loss of $4.8 \%$ of the total reported cases.

In relation to the sociodemographic characteristics of the studied population, $26(65 \%)$ participants were male and $14(35 \%)$ were female.

The age groups found were as follows: 13 (32.5\%) individuals (children and adolescents) were 8 to 19 years old, $14(35 \%)$ were 20 to 50 years old, and 13 (32.5\%) were 51 years of age and older. Among the patients who had adverse reactions, $57.1 \%$ were females older than 50 years and $19.2 \%$ of them were male. Among the studied subjects, $62.5 \%$ were classified as non-white (individuals who had brown or black skin); $58.8 \%$ of men lived with their spouses, and $58.2 \%$ of women lived without spouses.
Regarding education, $20 \%$ of the subjects did not attend school; $25 \%$ had $1-4$ years of schooling and $55 \%$ had more than 5 years of schooling. In terms of occupation, $22.5 \%$ of patients were involved in rural activities (agriculture and livestock), whereas $77.5 \%$ of the patients worked in commerce, education, and other fields. In relation to the origin of these patients, $85 \%$ were from Governador Valadares; $15 \%$ came from other cities of the micro-region. Average household income for $40 \%$ (16) of the studied population was less than or equal to one minimum wage; $47.5 \%$ (19) received two to three minimum wages, whereas $12.5 \%$ (5) had average minimum wages equal to or higher than four.

The presence of comorbidities (diabetes, hypertension, renal failure, and other diseases) occurred in $57.1 \%$ of ATL female patients and in $30.8 \%$ of male patients. The mean age of the studied population was 38.05 years $(S D=20.04)$. The average age was 32.9 years $(S D=20.0)$ for men and 47.5 years $(S D=20.49)$ for women.

It was observed that $67.5 \%$ of patients had some type of adverse drug reactions (arthralgia, myalgia, arrhythmia, nausea, or poor appetite). In terms of gender, $92.9 \%$ of females had adverse reactions as compared with $53.8 \%$ of males.

Individuals with ATL showed the following adverse reactions: $42.5 \%$ had arthralgia (joint pain), 37.5\% had myalgia (muscle pain), $25 \%$ were inappetent, $17.5 \%$ had arrhythmias, $12.5 \%$ had fever, and $45 \%$ had other reactions. It was also noted that the average adverse effects was $2.07(S D=2.94)$ per patient, that is, each patient had two types of adverse drug reactions; the average was 1.77 ( $S D=1.75)$ for males and 2.64 ( $S D=1.75)$ for females.

Among the 40 patients studied, 38 had a clinically localized cutaneous form of leishmaniasis; of these, $80 \%$ had a single lesion, $15 \%$ had multiple lesions (two to three lesions), $2.5 \%$ had concomitant mucosal injury, and $2.5 \%$ had late mucous lesion. Most (77.5\%) patients started treatment within 6 months after the lesion appeared; $22.5 \%$ started treatment after 6 months had passed.

The Montenegro skin test (MST) was the most used laboratory test for the diagnosis of ATL; only $5 \%$ of the studied patients did not undergo the exam. The parasitological and histopathological diagnoses were $30 \%$ and $42.5 \%$, respectively. Among those patients who underwent tests for the diagnosis, the results were positive for $84 \%$ of MST examinations, $50 \%$ for the parasitological. For the histopathological, the parasite was found in $47.8 \%$; $52.2 \%$ were compatible.

After confirmation of the diagnosis of ATL, $75 \%$ of the patients underwent further examination, such as electrocardiogram (ECG), among other tests, to check renal and liver function before treatment with pentavalent antimony.

It was observed that $72.5 \%$ of the patients received regular treatment or had treatment regimen as recommended by the Ministry of Health; $82.5 \%$ of the patients returned monthly for three consecutive months for evaluation of clinical healing. Regarding the clinical progress of patients in the three-month period after drug administration, the results were as follows: $67.5 \%$ of participants had clinical healing (complete healing of the lesion), $22.5 \%$ were not healed (with healing of the lesion or no lesion remission), and $10 \%$ abandoned treatment (they did not return for clinical evaluation of the injury). In terms of successfully treated patients, $78.6 \%$ of females were successfully treated as compared with $61.5 \%$ of males. 
TABLE 1 - Relationship between adverse effects presented by patients with American tegumentary leishmaniasis and age, comorbidities, regularity, and healing and sex.

\begin{tabular}{|c|c|c|c|c|c|c|c|}
\hline \multirow[b]{3}{*}{ Variables } & \multicolumn{6}{|c|}{ Adverse effects } & \multirow{3}{*}{$\begin{array}{c}p \\
\text { value }\end{array}$} \\
\hline & \multicolumn{2}{|c|}{ yes } & \multicolumn{2}{|c|}{ no } & \multicolumn{2}{|c|}{ total } & \\
\hline & $\mathrm{n}$ & $\%$ & $\mathrm{n}$ & $\%$ & $n$ & $\%$ & \\
\hline \multicolumn{8}{|c|}{ Age (years old) } \\
\hline$\leq 50$ & 12 & 92.3 & 1 & 7.7 & 13 & 100.0 & 0.02 \\
\hline$>50$ & 15 & 55.6 & 12 & 44.4 & 27 & 100.0 & \\
\hline \multicolumn{8}{|c|}{ Comorbidities } \\
\hline yes & 12 & 75.0 & 4 & 25.0 & 16 & 100.0 & 0.32 \\
\hline no & 15 & 62.5 & 9 & 37.5 & 24 & 100.0 & \\
\hline \multicolumn{8}{|c|}{ Abandonment } \\
\hline yes & 2 & 50.0 & 2 & 50.0 & 4 & 100.0 & 0.39 \\
\hline no & 25 & 69.4 & 11 & 30.6 & 36 & 100.0 & \\
\hline \multicolumn{8}{|l|}{ Regularity } \\
\hline yes & 20 & 69.0 & 9 & 31.0 & 29 & 100.0 & 0.51 \\
\hline no & 7 & 63.6 & 4 & 36.4 & 11 & 100.0 & \\
\hline \multicolumn{8}{|l|}{ Healing } \\
\hline yes & 19 & 70.4 & 8 & 29.6 & 27 & 100.0 & 0.51 \\
\hline no & 6 & 66.7 & 3 & 33.3 & 9 & 100.0 & \\
\hline \multicolumn{8}{|l|}{ Sex } \\
\hline male & 14 & 53.8 & 12 & 46.2 & 26 & 100.0 & 0.01 \\
\hline female & 13 & 92.8 & 1 & 7.2 & 14 & 100.0 & \\
\hline
\end{tabular}

Note: ${ }^{*} p<0.05$ (Chi-square test).

In this study, there were four cases of abandonment of treatment. A 75-year-old patient experienced severe adverse effects of the drug (myalgia, arthralgia, nausea, vomiting, fever, and prostration), which caused the patient to quit the treatment. Table 1 shows that individuals over 50 years old had a higher frequency of adverse effects than individuals under 50 . Individuals over 50 years of age had a $66 \%$ higher prevalence of adverse effects than people aged 50 years or under $(95 \% \mathrm{Cl}, 1.14-2.41)$. The mean age of individuals who reported some type of adverse effects was 44.11 years $(S D=20.14)$, while the group that had a mean age of 25.46 years $(S D=18.37 ; p<0.01)$ reported no adverse reaction. The difference between the means was tested by Student's $t$ test, and it was found that the mean age of individuals who had adverse effects was higher than the mean of those who had no adverse reactions. Logistic regression analysis was performed to identify the odds ratio between side effects and age. The results showed that being older than 50 years old increases the chance of occurrence of side effects ( $O R=9.60-95 \%-C l, 1.08-84.64)(p=0.04)$.

\section{DISCUSSION}

The incidence of ATL was predominant in men (65\%) with a mean age of 33 years. This result was also found in other studies ${ }^{11-13}$. However, from 2001 to 2006, the number of reported cases in the City of Governador Valadares was similar for both genders, as 127 cases of ATL were male patients (52.7\%) and 114 (47.3\%) cases were female patients ${ }^{14}$.

The presence of the disease was observed in all age groups, from children to seniors. A similar result was observed in the macroregion of Campinas, State of São Paulo, Brazil, where children and the elderly were infected, a probable result of vector adaptation to the peridomestic region, as these age groups often tend to stay in their homes or close to them ${ }^{13}$. For ATL treatment, the drug used was pentavalent antimony, which may cause significant adverse effects. In this study, $67.5 \%$ of patients showed some type of adverse effect, and the most frequently reported were cases of arthralgia (42.5\%), myalgia (37.5\%), inappetence (25\%), arrhythmias (17.5\%), and fever $(12.5 \%)$. These results coincide with those already described in the literature ${ }^{6,9,15}$.

With regard to age, a higher frequency of adverse effects was observed in individuals over 50 years old, at a rate of $66 \%$, a result higher than that of the group aged 50 years and under. A 75-year-old female patient was also registered as having abandoned treatment due to severe adverse effects. The Ministry of Health recommends that patients over 50 years of age undergo a rigorous clinical evaluation before and during treatment, including electrocardiographic monitoring twice a week, a complete blood count and a biochemistry blood test for evaluation of kidney (urea and creatinine), pancreatic (amylase and lipase), and liver (transaminases, bilirubin, and alkaline phosphatase) function. Such tests should be monitored weekly to guide the dose reduction as well as the probable use of alternative therapy'. In this study, we found that these patients had their clinical evaluation just before drug administration and were not monitored during treatment as recommended by the Ministry of Health. When the adverse reactions between genders were compared, it was found that the percentage of women (92.9\%) who had some type of adverse reaction was higher than the percentage of men (53.8\%), probably because $57.1 \%$ of women were over 50 years old, while $19.2 \%$ of men were in this age group.

The clinical healing rate was $67.5 \%$, a ratio close to those described in other studies ${ }^{9,14,15}$.

The Ministry of Health recommends that patients, even when healed, should be observed for a period of 12 months after conclusion of the treatment regimen for the possibility of relapse. Therefore, after post-therapeutic monitoring during the first quarter (when consultations should be monthly), a period of nine months with bimonthly visits should follow. In this context, adherence to the recommended full monitoring is even lower, because as soon as there is healing of injuries, if the patient is not properly guided, the need for clinical monitoring can be undervalued.

Pentavalent antimony is still the first drug of choice for the treatment of ATL. However, this may present some disadvantages, such as the dependency on multiple injections, long post-treatment regimen, and the possibility of the patient presenting major adverse effects, especially in individuals over 50 years of age, as well as contraindications for pregnant women. To reduce the cases of abandonment of treatment regarding ATL and to get a better response to treatment, it is important to have a better monitoring of patients, which can be performed by health professionals forming part of a wider network of care, following strict treatment criteria adopted by the Ministry of Health, so that patient adherence to treatment and recovery of health status takes place with minimal physical and/or social sequelae.

\section{CONFLICT OF INTEREST}

The authors declare that there is no conflict of interest. 


\section{ABSTRACT IN PORTUGUESE}

Efeito da idade na frequência das reações adversas provocadas pelo antimônio no tratamento de pacientes com leishmaniose tegumentar americana, em Governador Valadares, Estado de Minas Gerais, Brasil

Introdução: Governador Valadares constitui uma área endêmica de leshmaniose tegumentar americana (LTA) e o coeficiente de detecção foi de 15,36/100.000 habitantes no período de 2001 a 2006 (Miranda, 2008). Este estudo teve como objetivo analisar o efeito da idade na frequência das reações adversas provocadas pelo antimônio no tratamento de pacientes com LTA, em Governador Valadares, Estado de Minas Gerais, Brasil, no período de janeiro a dezembro de 2009. Métodos: Para coleta de dados foram utilizados: ficha de notificação do Sistema de Informação de Agravos de Notificação (SINAN), prontuários, questionário e visitas domiciliares aos pacientes. Resultados: Participaram do estudo 40 pacientes, sendo 26 (65\%) do sexo masculino. Os indivíduos acima de 50 anos de idade tiveram prevalência $66 \%$ maior de reações adversas que as pessoas com idade de 50 ou menos (IC 95\% - 1,14-2,41). A média de idade dos indivíduos que relataram algum tipo de reação adversa foi de 44,11 anos ( $D P=20,14)$, enquanto no grupo que não relatou reação adversa, a média de idade foi de 25,46 anos ( $D P=18,37)$ e $p<0,01$. A cura clínica foi de $67,5 \%$ e $10 \%$ dos pacientes abandonaram o tratamento. Conclusões: No tratamento da LTA, a idade do paciente deve ser considerada; pois ocorrem mais reações adversas em indivíduos acima de 50 anos de idade, que nesses casos o medicamento deve ser utilizado com restrição.

Palavras-chaves: Leishmaniose tegumentar americana. Tratamento. Governador Valadares.

\section{REFERENCES}

1. Ministério da Saúde. Departamento de Vigilância Epidemiológica. Manual de Vigilância da Leishmaniose Tegumentar Americana. $2^{\text {nd }}$. ed. Brasília: Editora do Ministério da Saúde; 2007.

2. Lima MVN, Oliveira RZ, Lee AP, Felix MLO, Silveira TGV, RM Rossi, et al. Atendimento de pacientes com leishmaniose tegumentar americana: avaliação nos serviços de saúde de municípios do noroeste do Estado do Paraná, Brasil. Cad Saude Publica 2007; 23:2938-2948.
3. Gontijo B, Carvalho MLR. Leishmaniose tegumentar americana. Rev Soc Bras Med Trop 2003; 36:71-80.

4. Azeredo-Coutinho RBG, Mendonça SCF. The intermittent schedule of antimonial therapy is superior to continuous therapy of cutaneous leishmaniasis in the towns of Rio de Janeiro, Brazil. Rev Soc Bras Med Trop 2002, 35:477-481.

5. Marsden PD. Pentavalent antimonials: old drugs for new diseases. Rev Soc Bras Med Trop 1985; 18:187-198.

6. Passos VMA, Barreto SM, AJ Romagna, Krettli AU, Volpini AC, Gontijo CMF, et al. Leishmaniose tegumentar na Região Metropolitana de BeloHorizonte: aspectos clínicos, laboratoriais, terapêuticos e evolutivos (1989-1995). Rev Soc Bras Med Trop 2001; 34:5-12.

7. Saldanha ACR, Romero GAS, Guerra C, Merchan-Hamann E, Macedo VO. Estudo Comparativo entre estibogluconato de sódio BP $88^{\circledR}$ e antimoniato de meglumina no tratamento da leishmaniose cutânea II. Toxidade bioquímica e cardíaca. Rev Soc Bras Med Trop 2000; 33:383-388.

8. Soto J, Toledo J, See J, Berman J. Efficacy of pentavalent antimony for the treatment of Colombian tegumentary leishmaniasis. Am J Trop Med Hyg 2005; 72:421-422.

9. Rodrigues AM, Hueb M, Santos TARR, Fontes CJF. Fatores associados ao insucesso do tratamento da leishmaniose cutânea com antimoniato de meglumina. Rev Soc Bras Med Trop 2006, 39:139-145.

10. Serviço de Apoio as Micro e Pequenas Empresas de Minas Gerais (SEBRAE-MG) [Internet]. Belo Horizonte (MG): SEBRAE; [cited 2009 March 6]. Available from: http://www.sebraemg.com.br/Home/homeportal.aspx/.

11. Araújo HNS, Machado MI, Rocha A, Cury MCC. Clinical and pathologic features of American tegumentary leishmaniasis in patients seen in Hospital das Clínicas, Federal University of Uberlandia, Minas Gerais, Brazil, Uberlandia. Rev Patologia Trop 2008; 37:23-31.

12. Reis LC, Brito MEF, Almeida EL, Felix SM, Medeiros ACR, Silva CJ, Pereira, et al. Clinical, epidemiological and laboratory Aspects of American cutaneous leishmaniasis with Patients in the State of Pernambuco. Rev Soc Bras Med Trop 2008, 41:439-443.

13. Silva LMR, Cunha PR. A urbanização da leishmaniose tegumentar americana no município de Campinas São Paulo (SP) e região: magnitude do problema. An Bras Dermatol 2007; 82:515-519.

14. Miranda, TM. Caracterização clínico - epidemiológica e distribuição espacial da leishmaniose tegumentar americana no período de 2001 a 2006 no Município de Governador Valadares, Minas Gerais, Brasil. [Master's Thesis]. [Governador Valadares (MG)]: Universidade Vale do Rio Doce; 2008. 75 p.

15. Nogueira LSC, Sampaio RNR. Estudo hospitalar da leishmaniose tegumentar americana (LTA): epidemiologia e tratamento. Dermatology 2001; 76:51-62. 